\title{
Living in the Borderlands: A Postcolonial Reading of Nerdeen Abu-Nab'ah's Oh, Allah, I Delivered a Female Child
}

Shadi S. Neimneh*, Abdullah B. Al-Sheik Hasan, Abdullah F. Al-Badarneh, Asma H. Badran

Hashemite University, Jordan

Corresponding Author: Shadi S. Neimneh, E-mail: shadin@hu.edu.jo

\section{ARTICLE INFO}

Article history

Received: March 24, 2018

Accepted: June 21, 2018

Published: August 31, 2018

Volume: 9 Issue: 4

Advance access: July 2018

Conflicts of interest: Non

Funding: None

Key words:

Abu-Nab'ah,

Anzaldua,

Bhabha,

Du Bois,

Borderlands,

Double Consciousness,

Cultural Hybridity.

\begin{abstract}
Within a postcolonial theoretical framework, this article highlights the political struggles and cultural displacement of Palestinians using a recent novel published in 2013 and entitled (Oh, Allah, I Delivered a Female Child) by (Nerdeen Abu-Nab'ah). It investigates the meaning of living in the borderlands and the effects of double consciousness on the main characters/ narrators: Abbas, his brother Abu-Raja, and his daughter, Miriam, who visits Gaza strip in Palestine for the first time in her life. The analysis shows that Abu-Nab'ah strongly believes in such idea as the borderlands being the place most Palestinians inhabit physically and symbolically inside and outside their homeland because of the oppression and discrimination they face. The article examines the complicated interrelationships among ideas of dislocation/ exile, the (in)visible borderlands, and double consciousness by applying the theories of Gloria Anzaldúa, W.E.B. Du Bois, and Homi Bhabha. Moreover, it interrogates the role of memory in reconstructing a national story about resistance and exile while simultaneously endorsing the role of women in documenting national loss and revolution. The result is a tale of cultural resistance against dislocation and exile and an articulation of the predicament of being a stranger within one's country and abroad.
\end{abstract}

\section{INTRODUCTION}

"Hereby I have discovered that home has a magical reach, and that it could arise from the frost of exile." (Abu-Nab'ah 20)

Critical studies on Palestinian literature tend to focus on famous pieces by well-known writers such as Ghassan Kanafani, Mahmoud Darwish, Ibrahim Touqan, among others. However, scholars have not paid adequate attention to the postcolonial aspects of such works or the repercussions of declaring Israel as an independent country in the Palestinian land. This declaration not only changed Palestine's name to Israel in history books, but it also affected the world's point of view towards the right to resist. Palestinian writers, therefore, consider their works as a cultural weapon that can be used to oppose the colonizer, remind the world of the realities of their struggles, and answer urgent political questions. The question posed by the most recent novels, political commentaries, and studies about the Palestinian cause is: would it better for Palestinians and Israelis to live together in peace? Many Western politicians urge Palestinians to live in peace with the Israelis and accept Israel as the only sovereign entity in the historical land of Palestine. In response to this idea, this article investigates the main questions raised in Nerdeen Abu-Nab'ah's novel Oh, Allah, I Delivered a Female Child (2013) to maintain that Palestinians could not simply live in peace with the colonizer, nor could they have inner peace outside their homeland. The proposition that Palestinians seek peace, we argue, is too simplistic and detached from the realities of both physical and inner struggles that people face under occupation.

Conflicts and misunderstandings related to colonialism have been common in Palestinian literature since 1948 because of the misleading role that the world media sometimes promulgates. The media often (mis)represents Palestinians as "traitors" but depicts Israeli people as "fighters" for their own land. In Abu-Nab'ah's novel, the character Abbas underlines this mistaken assumption when he objects: "Because we are simply repeating the same story which Zionists have propagated one day; that it was Palestinians who sold their land, and that Jews bought it with their own money" (103).

This distorted tale prevailed even before the establishment of the state of Israel in 1948, which made it hard for people around the world to understand why Palestinians struggle to get their freedom, and they also started to blame Palestin- 
ians for their resistance. When Palestinians understood the public relations campaign against their case, they chose to resist in order to make the truth prevail. In an interview, AbuNab'ah states that the Zionists use the media and "we" are going to do the same by writing novels and spreading songs too. So, by writing authentic novels Abu-Nab'ah chose to stand against the colonizer and to reveal the truth through the cultural realm of writing. In one interview, Abu-Nab'ah highlights the politicized nature of her fictional endeavors

For me, writing novels is the weapon with which I can face oppression, tyrannies, and the Zionist occupation. And because literature is one of the most important battles which the nation fights, I decided to fight this battle. For example, The Holocaust movie reports the story of one of the survivors in the holocaust. Literary Zionism has surpassed political Zionism; literature has been produced and employed in the Zionist schemes (Ghassan Kanafani's study on Zionist literature). Therefore, if I tell you that I write to win the support of others for myself and the Palestinian cause, I will say yes, as I am writing to keep my homeland present in all minds. (Abu-Nab'ah; Personal Interview)

A contemporary Palestinian writer and novelist, Abuرب اني وضعتها : ربbا

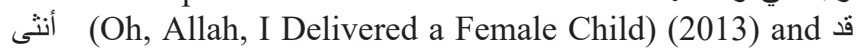
شغفها حباً (He Enticed Her Heart) (2015).

In both novels, she has focused on Palestinian issues like living in the borderlands, the role of the Palestinian women, resistance inside and outside Gaza strip, and the frustrations that any Palestinian might have. In addition to novels, she has written a huge number of articles and short stories about the same issue. Abu-Nab'ah currently presents a program on Hayat FM radio in Jordan. Her novel, $\mathrm{Oh}, \mathrm{Al}$ lah, I Delivered a Female Child, has not received adequate critical attention, aside from few and very short book reviews written in Arabic in local newspapers in Jordan. Therefore, it is our goal in this article to complicate her stance on the difficult position of the Palestinians who are not treated as full citizens in their homeland and who feel strangers outside Palestine. Through examining this unexplored, contemporary Arabic novel and translating related portions, it is our aim to present it to the English language readers by way of lifting "the veil" and, thus, communicating an alternative vision for the Palestinian case.

Not only does Abu-Nab'ah pose questions and give answers in her cultural productions, but she also seeks change as well, giving readers a new perspective through which they can investigate the truth, especially after the recent and repeated attacks on Gaza (the last major one being in 2014). Oh, Allah, I Delivered a Female Child aims to stimulate readers' imagination and make them ask themselves about the Palestinian identity inside Palestine or in the diasporic space. Moreover, it aims to remove the veil by providing adequate evidence of the truth, which the writer personally gathered from Gaza when she was there. As a result, AbuNab'ah smartly makes use of her personal experience in Gaza to support the Palestinian cause. Briefly put, Oh, Allah, I Delivered a Female Child is not only an interesting novel but also a politically authentic one and a historically significant document. It draws on real and imaginative incidents to demystify many of the inaccuracies about the Palestinian issue and reawaken its cause, thus contributing to a project of cultural resistance against the oppression of Palestinians and their dislocation from their homeland or being treated as strangers in their own country.

This novel has three narrators collaborating to establish reliability, each playing the role of the first, second and even third point of view depending on the story. Moreover, the novel has a lot of stories within the main story, especially stories about women's resistance in Gaza. AbuNab'ah uses labels in her novel to represent the narrators, so at the begin-ning of each chapter she writes (هي) \{she\} when Miriam is the narrator, (هو 1 (هe $\{$ hel which means that Abbas is narrat-ing now, and (هو (هو) 2$\}$ when Abu-Raja is telling his story. This style makes the narrative more interesting as readers might have to read the whole chapter to know who the narra-tor is. The next section explores this novel with a focus on its treatment of the idea of "borderlands" created by occupation and exile, employing the theories of W.E.B. Du Bois, Homi Bhaba, and Gloria Anazaldúa to investigate the main ques-tion that AbuNab'ah dramatically poses through her charac-ters: how does it feel to be a problem in your own country and even in exile?

\section{OH, ALLAH, I DELIVERED A FEMALE CHILD: THE MULTIPLE BORDERLANDS}

Palestinian novelists aim to reflect the inner conflicts that most Palestinians have. Recent novels were designed to reflect their real life under occupation or blockade. A Palestinian has to deal with the colonizer as a new ruler is expected to follow orders. He or she is seen as a problem in their own country, with an Israeli state inside Palestine. This idea of being a problem in your own home is not new. The Mexican-American writer Gloria Anzaldúa describes the borderlands in the following terms:

Borders are set up to define the places that are safe and unsafe, to distinguish us from them. A border is a dividing line, a narrow strip along a steep edge. A borderland is a vague and undetermined place created by the emotional residue of an unnatural boundary. It is in a constant state of transition. The prohibited and forbidden are its inhabitants (Borderlands/La Frontera 3 ).

Anzaldúa defines the borderlands as the ambivalent space inhabited by the marginalized and excluded. Strangers, or those who are estranged, intensely feel this borderlands state of uncertainty. Anzaldúa asserts that the borderlands are turbulent spaces of political tension: "Tension grips the inhabitants of the borderlands like a virus. Ambivalence and unrest reside there and death is no stranger" (4). The borderland is also the space of discrimination, exploitation, and alienation. It is being unsure where to place your home on a map and how one is seen by others. Anzaldúa confirms the state of psychic confusion caused by the borderland experience and finds that to be a productive space for the creative writer; she says: "Living in a state of psychic unrest, in a Borderland, is what makes poets write and artists create" (73). Understandably, Anzaldúa was writing about the Latin American cultural context and the multiplicity of identities, i.e. being 
queer, Chicano, woman, ...etc. However, the crossroads identity of half and half, neither one nor the other, remains the essential experience of her border theory, and her comments are still relevant due to the separation/security fence between the West Bank Palestine and Israel. A similar scenario is significantly present. In each case, that contact zone between the settlers and the natives becomes an ambivalent site of contention. In addition, Palestinians living in many Arab countries, mainly Jordan, still struggle with identity issues although many of them got facilities like passports and citizenship.

A substantially germane line of thought comes from W.E.B. Du Bois who was the first to ask this relevant question in his book The Souls of Black Folk (1903): "How does it feel to be a problem?" (3). He also states that "being a problem is a strange experience,-peculiar even for one who has never been anything else" (3). Du Bois means speaking from within the veil of prejudice, feeling a stranger in one's own house, and constantly having that feeling of double consciousness; he memorably defines this double consciousness as:

this sense of always looking at one's self through the eyes of others, of measuring one's soul by the tape of a world that looks on in amused contempt and pity. One ever feels his twoness.two souls, two thoughts, two unreconciled strivings; two warring ideals in one dark body, whose dogged strength alone keeps it from being torn asunder. (4)

Double-consciousness causes self-alienation. Du Bois also speaks of being different from others, "shut out from their world by a vast veil" (4). He asks: "Why did God make me an outcast and a stranger in mine own house?" (4). While Du Bois has famously claimed that "the problem of the Twentieth Century is the problem of the color line" (2), we can also claim that for the Arab world, in general, and Palestinians, in particular, the problem of the twentieth century was the establishment of the Israeli State on Arab territories in Palestine and the subsequent scattering of Palestinians in refugee camps and elsewhere in the Arab region. Palestinians feel alienated in their homeland because Israel is perceived worldwide as an extension of the West and the Judeo-Christian tradition, and Palestinians do not belong in it according to that perspective. Not only that, but Palestinians are thought of as a threat to what Israel stands for morally and ethically (which is why Israel is often called the "only democracy" in the Middle East. This phrase implies that it should be protected from people who do not represent "democratic' values, especially Palestinians.

In a related line of thought and within a postcolonial framework, Edward Said once observed that "Exile is strangely compelling to think about but terrible to experience. It is the unbearable rift forced between a human being and a native place, between the self and its true home: its essential sadness can never be surmounted" (Reflection 137). Like other theorists, Said captures the essentially negative and difficult experience of exile and the entrapment between divergent cultures. On her part, Abu-Nab'ah aims to give an answer to Du Bois's question and Said's take on the notion of exile from a Palestinian perspective. Palestinians, as the novelist asserts, have been viewed as "different" and "inferior" in their own land and thus elsewhere. They have been exiled inside and outside Palestine as a result of the 1948 and 1967 events. This loss of land and subsequent dislocation left a scar on their lives, and Palestinians have been stigmatized accordingly.

Nowadays, many Palestinian novels can be considered as a representation of the feeling of confusion that each Palestinian who lives abroad has. In other words, no one can understand his/her thoughts, traditions or even resistance if there is a veil between him/her and other citizens. Abbas, who goes to Libya to work as a teacher, asserts that people like Egyptians, Libyans, Tunisians, and the Sudanese do not know much about the Palestinian issue. He says: "They have feelings ranging between blaming Palestinians and pitying them"(98). Abbas feels that he is like a germ among other Arabs in Libya. He has been rejected by the colonizer, and there is an invisible form of exile and rejection in Arab countries as well. The Egyptian teacher admits to Abbas that he, back in Egypt, had a wrong impression about Palestinians and that he was warned about dealing with them (99). The veil of misunderstanding and stereotyping foregrounds the misery of dislocated Palestinians. The notions of contempt and pity Du Bois attaches to the experience of "double consciousness" recur here when Palestinians deal with others.

Abu-Nab'ah emphasizes the idea of the veil (that of prejudice and discrimination) in different situations in her novel to draw a clear picture for Palestinians abroad. An example is the direct questions Abu-Alnoor, a Libyan citizen, directs to Abbas:

"-Why are you here?

-Why don't you go and fight to get back your land?" (101)

Abbas immediately answers that he is in Libya because he is exiled and cannot enter his homeland, with the neighboring Arab countries protecting the borders of Israel and not allowing "trespassing" (101). Any Palestinian who lives abroad daily saw this question in the eyes of people around him/her. Simply, this is because of an inability to clearly understand the real Palestinian case. The next question "Why did you sell your country?"(101), asked by Alujailly, another Libyan citizen, shows how the non-Palestinians think about the Palestinians in negative terms and see them only through the veil of historical inaccuracies. Abbas justifies the circumstances that led to this current dislocation:

"The land of Palestine was not handed over by its people to the Israelis.Palestinian lands were lost after the defeat of Arab armies in the 1948 war and the creation of the occupying power over $77 \%$ of Palestinian lands, and, then, directly rejecting its people and seizing their land with force. Then, the rest of Palestine was occupied in the aftermath of the 1967 war!!" (106)

For Palestinians who live abroad, it is really hard to give adequate answers or a full clarification of the truth. And if they fail to explain their existence outside their land, they would stay behind the veil of marginalization, misunderstanding, and inferiority. The idea of the veil as the invisible borderland is rare in Palestinian novels, and this makes AbuNab'ah's novel a psychologically special one. 
Homi Bhabha argues that when two cultures interact, a third interstitial, liminal space arises in between and requires a new conception of identity and belonging; he says: "These 'in-between' spaces provide the terrain for elaborating strategies of selfhood-singular or communal-that initiate new signs of identity, and innovative sites of collaboration, and contestation, in the act of defining the idea of society itself" (The Location of Culture 1-2). In the case of Palestine, Palestinian culture may be influenced and changed through interacting with the colonizer's culture. For example, Abu-Raja, one of the three narrators in the novel, has to daily deal with Israeli governors, traders, police officers and salesmen. He has to speak Hebrew with them whereas his mother tongue is Arabic. For men abroad like Abbas who lives in Libya, identity issues are still problematic. Those people have to deal with another language and culture, which problematizes their identity. As Bhabha points out,

the theoretical recognition of the split-space of enunciation may open the way to conceptualizing an international culture, based not on the exoticism of multiculturalism or the diversity of cultures, but on the inscription and articulation of culture's hybridity. To that end we should remember that it is the 'inter'-the cutting edge of translation and negotiation, the in-between space - that carries the burden of the meaning of culture. It makes it possible to begin envisaging national, antinationalist histories of the people. And by exploring this Third Space, we may elude the politics of polarity and emerge as the others of ourselves. (emphasis original; 38-39)

This interaction and negotiation of cultural difference and identity politics appears through the process of rebuilding of Abbas's identity throughout the novel. So, he is in-between, half Palestinian and half Libyan in most of his behaviors. That imposed hybrid space Abbas inhabits, however, is neither fortunate nor productive. For example, the case of Abbas is devoid of Bhabha's relative optimism. Abbas is surprised when he realizes that Libyans buy olive oil from other countries while they have olive trees. He muses: "The Libyan goes to buy Italian and Tunisian olives and olive oil and lets his tree expire!!" (62). Abbas wanted to act as a Palestinian peasant and make olive oil using his hand rather than buy it, but he could not. So, he was unable to play his traditional role and practice his identity; rather, he was forced to mimic another cultural role forced on him in many cases. This imitation was still not total because of his desire to go home and his constant awareness that he is not Libyan. Moreover, he is fighting to save his tradition, which makes him a hybrid of two cultures but not fully experiencing or absorbing either. Describing this borderline as an in-between situation, Bhabha aptly writes describing the other of colonial discourse: "almost the same, but not quite" (86). Abbas is constantly aware that he is neither a full Libyan citizen nor a Palestinian peasant. He is a quintessential example of living in the borderlands with all contradictions and antagonisms involved.

Abu-Nab'ah highlights that living abroad or in Palestine changes nothing about the discrepancy between having a homeland and not having one. For instance, to live in the borderlands, for Palestinians, means that they are neither Palestinians nor Israelis in the same country. To live in the borderlands, when Palestinians are abroad, means that they cannot be Palestinians and cannot be anything else. Anzaldúa, the Chicana theorist and poet, suffered from the same issue when she was in the United States, which led her to publish her book Borderlands/La Frontera to point to this universal feeling of angst. Anzaldúa has summarized the meaning of living in the borderlands and being a stranger in your home. In an expressive poem in this book, she states the following:

In the Borderlands

you are the battleground

where enemies are kin to each other;

you are at home, a stranger,

the border disputes have been settled

The volley of shots have shattered the truce

You are wounded, lost in action

Dead, fighting back; (194

For Anzaldúa, to live in the borderlands entails identity loss and confusion, lack of connection with roots, being torn between different affiliations, and difficulty in coping with the present while not forgetting the painful past. Moreover, living in the borderlands means, for Anzaldúa, a feeling of insignificance, spiritual sterility, and victimization. It is a sense of being caught between two cultures, Mexican and American in her case, and thus inhabiting the torturous zone of hybridity. It is this general sense of disorientation/alienation caused by mental barriers and invisible borders that we project in Abu-Nab'ah's Oh, Allah, I Delivered a Female Child. In this novel, characters inhabit the borderlands space whereby they feel estranged from their own Palestinian culture as well as the other culture they encounter. This identity loss and confusion creates "borderlanders" like the characters we meet in this novel.

Miriam plays the role of the main narrator in the novel, being the one who breaks the rules and goes to Gaza after the last war. She narrates women's stories about their role in Gaza and embodies the idea that Abu-Nab'ah focuses on, i.e. women-just as men-being the essence of resistance and victory as well as the carriers of national memory. She gets to hear the story of Um Nidal Al Farahat who hosted a militant fighte, Imad Akil, in her own house until he got killed by the Zionists. Another story Miriam attentively hears to enrich her national reservoir is that of Mo'menah who waited for her imprisoned fiancé for more than sixteen years because he gave his soul to his country and defended his land. Mo'menah rejects the borderline status. She adopts, instead, the path of resistance inside her country. She says: "I have discovered that there is no homeland for those who do not take sides or stand askew neither here nor there!!" (84). Palestinians are forced to leave their land and are rejected by other countries. They are in-between and in the middle of nowhere. And when imprisoned, like Abu Raja, they assume the borderlands status of double exile within their own occupied land. Abu Raja says: "With bars, Jews think that they cover the whole story!! But here am I observing life from behind 
the bars. the voice of my mother speaks to me with much fortitude about her ecstasy and pride in such bars.with her voice my feeling for my country gets stronger!!" (118). Abu Raja legitimately appeals to an established metaphorical association between the personal mother and the "motherland."

Abu-Raja, Abbas's brother, stays in Palestine to fight and get back his land. For that, Israel considers him as a problem and imprisons him for several years. In this novel, Abu-Raja symbolically answers Du Bois's question, "how does it feel to be a problem" in your country? (3). Seen as a threat and a problem in his own homeland, Abu-Raja is imprisoned, tortured, and mistreated. On the other hand, Miriam is uncertain as to whether she has a homeland or not because she cannot live in or even visit Palestine. Abbas, Miriam's father, spends a decade of his life in Palestine as a child before his homeland gets colonized, and he is cast out. So, he stays in Amman for five years before settling in Libya to make a living from teaching. He is a well-educated character, and a real representation of a Palestinian living in the borderlands. Such characters share an experience of dislocation from their country or even within their country. This unnatural feeling they have is what constitutes the borderlands experience for them. They are seen as a problem inside and outside their country.

Abu-Nab'ah follows Du Bois' lines of encouraging the folks to seek change. She asks the questions that would stimulate the reader's desire to find the truth. Throughout the novel, the reader will find that acknowledgment is not enough as it is time to seek change. Also, the novelist assumes that each one, even the non-Palestinian, has to have a role in removing the veil and standing by Palestinians to get their land back. Abu-Nab'ah's characters, like Miriam's friends with whom she travels to Gaza, play an important role in manifesting this argument. For example, her Saudi friend Buthaina shouts at the Egyptian policeman-on the Rafah crossing point-for replicating the colonizer's discriminatory actions; she says: "No, I swear to God, we will not get into Palestine unless the female Palestinians are with us" (15). It is ironic that Palestinians are not allowed to enter their country and are seen from behind the veil of discrimination. This confirms the view that they ar seen as a problem in their country. And since they inhabit the uncertain borderline status, they get to their country but get rejected. They are almost there, but not quite! In this regard, Bhabha argues: "It is in the emergence of interstices-the overlap and displacement of domains of difference-that the intersubjective and collective experience of nationness, community interest, or cultural values are negotiated (2). What is questioned here is not only Miriam's right to belong to a nation and have a national identity, but also her basic human right of a decent, equal treatment. Miriam becomes "the stranger," the odd one out in her own land.

Anzaldúa very broadly describes the problem of living in the borderlands (the U.S.-Mexican border in particular) with much elaboration and expertise. She states that what creates borderlands is not the physical borders, but rather the invisible spiritual and the psychological borders that people have when they leave their country. In the borderlands, one cannot keep one's own traditions nor replace them with the new land's traditions. This builds a gap between people and the new society into which they have to merge. The mental borderlands as well as the physical ones are spaces of a constant struggle for identity and national affiliation. For Anzaldúa, the border pulls people to be something new and original. And at the same time, it pulls them to stick to the traditions. The borderlands can tear parts of you apart while building other parts up. The borderland is an ambivalent and vague space where two worlds meet to form a border culture. Anzaldúa shows how Texas was part of Mexico in the 1800s and how Anglos drove the native Texan-Mexican inhabitants out of their lands violently and as part of imperialistic attempts (6). This means that borderlands can be created violently. Anzaldúa says: "By the end of the nineteenth century, powerful landowners in Mexico, in partnership with U.S. colonizing companies, had dispossessed millions of Indians of their lands" (10). Gaza was created in this violent way! The lands surrounding it were seized and this strip was besieged, often raided and bombed too. It had been under Israeli occupation from 1967 to 1994, and constantly under heavy border security measures or strict blockades thereafter. Since then, it has been under Palestinian self-rule.

Abbas struggles to forget everything about his identity and replace it with a new one. And each time he thinks that he has done it, he discovers that he has failed again. He ponders: "While you are abroad, you may think for a while that you have left everything behind you!! Sometimes you may feel deeply grateful to exile! You may also think that you finally got rid of your haunting house keys!" )126). In this example, Abbas clearly says that he is struggling to forget the traumatic past. He was dominated by the feeling of discrepancy between his desire to forget everything and his feeling of loss. The exiled Abbas says:"I wonder what Adam felt when he descended to earth for the first time. Is his feeling similar to mine now- a lost butterfly that does not find its fire? A torn string? A missing key? All of that is how I felt when I moved to this land." (18) By comparing himself with Adam, who came down to earth f rom heaven, Abbas wants to emphasize that it is not a matter of where he is now-he does not mention Libya-but it is a matter of being cast out from his homeland (his "heaven") and being lost, unable to go to his homeland. The feeling of loneliness Abbas has is developed by his attempt to be separated from his culture. Anzaldúa has the same feeling in Texas; she says:

I was totally immersed en lo mexicano, a rural, peasant, isolated, mexicanismo. To separate from my culture (as from my family) I had to feel competent enough on the outside and secure enough inside to live life on my own. Yet in leaving home I did not lose touch with my origins because lo mexicano is in my system. I am a turtle, wherever I go I carry "home" on my back. (21)

So, this is the issue of being in the borderlands which Anzaldúa defines as an ambivalent space created by "unnatural" boundaries (3). Regardless of where the characters are, they carry their "home" within and make it live and prosper in their minds. 
Abbas does not care about his physical location. All lands but his homeland are borderlands in which he is a stranger. He contends: "There is a homeland which I have lost there. So all lands other than mine are the same." (18) The feeling of loss, dislocation, and alienation is present here. Again, Abbas tries to put his Palestinian traditions aside in order to escape from the feeling of being a stranger; he fails to forget his cause and his role of resistance. The next example emphasizes this argument:'I spent forty years between the east and the west of the Arab world. But my homeland from which I had been pulled out blames us and is redolent of the smell of blood" (19). In this displacement, the "unhomely" condition finds a good outlet. To use the words of Bhabha, "The negating activity is, indeed, the intervention of the 'beyond' that establishes a boundary: a bridge, where 'presencing' begins it captures something of the estranging sense of the relocation of the home and the world-the unhomeliness - that is the condition of extra-territorial and cross-cultural initiations" (9). On the other hand, Abbas simultaneously feels like he has a homeland but that he does not belong to one. This discrepancy causes him to be sad all the time remembering his old days in Palestine. He is a stranger in Libya. However, his life there constantly makes him aware of his home. Ironically, his exile-unhomeliness caused by the condition of migratory life-makes his sense of symbolic homelessness more acute.

Everything reminds Abbas of his state of exile in Libya. So, being in the borderlands means being a hybrid with no clear identity, traditions, and vision for anything. It is not being able to lead a normal life with peace of mind. Upon first moving there, Abbas keeps comparing things around him in Libya with the things that he left in Palestine. He captures Bhabha's ambivalent construction of the hybrid scenario and Du Bois's conception of double-consciousness when he says:

"The house is surrounded by orange trees. I pick an orange. I get astonished by its smell, its brightness and its sway between my infatuated fingers. assume that it is a Palestinian orange ... How hard it is to have your homeland in your hands and not have it!" (21)

In addition, the feeling of being a stranger in Libya hinders his attempts to seamlessly assimilate with the Libyan identity. So, he feels guilty for having abandoned his home country. In each attempt he makes to adapt to the Libyan culture, Abbas is pulled back by the Palestinian culture. His sense of fragmentation reveals that he no longer regards Palestine as a home and he cannot consider Libya as a home either. Bhabha says that "it is the space of intervention emerging in the cultural interstices that introduces creative invention into existence. And one last time, there is a return to the performance of identity as iteration, the re-creation of the self in the world of travel, the resettlement of the borderline community of migration" (9). However, this creative agency Bhabha articulates does not work in the case of Abbas who is repeatedly reminded of his loss. Similarly, Anzaldúa struggled with this dislocation when she left Mexico; she says: "Separated from Mexico, the native Mexican-Texan no longer looked toward Mexico as home" (7). However, the native Mexican could not see America as the new home either. When underscoring how the feeling of being an exile makes him constantly aware that he is away from his native country, Abbas says:"Hereby I have discovered that home has a magical scope, and that it could arise from the frost of exile" (20). Against the visible and physical borders, his country lives inside him as a psychological state of obsession. He is appointed to teach in a Libyan city named after his native town in Palestine, Al-Zawia, which puzzles him. This is the same feeling he has when he touches an orange from a tree planted near his rented house in Libya and imagines it to be a Palestinian orange. Trees of oranges and cactuses remind him of Al-Zawya and his home there in Palestine although he is in his rented house in the Libyan Zawya. Caught between two cultures but belonging to neither, Abbas embodies the culturally displaced Palestinians in the diaspora. Explicating Bhabha's notion of "unhomeliness", Lois Tyson asserts that to be "unhomed" means feeling not at home "even in your own home because you are not at home in yourself: your cultural identity crisis has made you a psychological refugee" (421). In Libya, Abbas lives in a physical as well as psychological limbo.

As for Abu-Raja, the fact of being a problem in his country is also the dominant theme in the sections he narrates. In the African American context, Du Bois was a child but he noticed that others treat him as a problem just because of his color. White students, for example, did not allow him to be in their classes at school. There was one side in each classroom for whites and another for blacks. In Palestine as well, Israelis have built a great wall around their settlements and segregated Palestinians. Du Bois comments on the implicit status of being seen as a problem in one's country simply because one's skin color or ethnicity is different:

Between me and the other world there is ever an unasked question: unasked by some through feelings of delicacy; by others through the difficulty of rightly framing it. All, nevertheless, flutter round it. They approach me in a half-hesitant sort of way, eye me curiously or compassionately, and then, instead of saying directly, How does it feel to be a problem? they say, I know an excellent colored man in my town; or, I fought at Mechanicsville; or, Do not these Southern outrages make your blood boil? At these I smile, or am interested, or reduce the boiling to a simmer, as the occasion may require. To the real question: How does it feel to be a problem? I answer seldom a word. (3)

Abu-Raja confirms the idea of being viewed as a problem and getting imprisoned and culturally silenced accordingly. In this instance, he says: "Who would think that the sunlight and the Arabic letter are going to be the Palestinian prisoner's greatest wish." (46) He wonders about the situation of disfranchised Palestinian prisoners. The colonizer not only imprisoned him but also prevented him from speaking his language too. The symbol of Arabic language here indicates that the colonizer imprisoned Palestinians not necessarily because of their bad attitude or their bad behavior. The colonizer considers Palestinians a problem 
because of the identity which they were born with. The colonizer, hence, prevents them from speaking or listening to their language, attempting to change their identity and natural preferences. For example, Abu-Raja is asked to stop his resistance and live in peace with the occupier. In the prison, the guardians speak Hebrew with him on purpose. So, whether he wants that or not, he should learn and speak Hebrew. This language enforcement intentionally changes his personality. Even in everyday life, Palestinians are expected to speak Hebrew to understand what happens around them or to make their life easier. Moreover, if Palestinians want to live in peace in Israel, they should mimic the Israeli culture. This imitation leads to changes in desires, aims, personalities, and culture. Colonizers aim to change the culture of the colonized space to make it like theirs; thus, enforced mimicking is the best way to achieve this goal.

So, this is the main reason why Israelis prevent Palestinian prisoners from speaking Arabic. As time passes, they unconsciously mimic the culture and become hybrids. Palestinians are made to speak Hebrew, use Israeli coins, buy from Israeli markets and use Israeli passports too. As Bhabha has demonstrated, mimicry "emerges as one of the most elusive and effective strategies of colonial power and knowledge" (85). Palestinians get engaged in the Israeli culture, so unconsciously and smoothly they adapt to this foreign culture. They are caught in what Bhabha calls a web of "double articulation; a complex strategy of reform, regulation and discipline, which appropriates the 'other' as it visualizes power" (86). This imposed mimicry applies to Palestinian prisoners in Israeli prisons, like Abu-Raja in the novel.

Unlike the other two narrators who have a memory relating them to an occupied Palestine, Miriam-due to her age-has no memory of her country. She tries to establish one through her visit to Gaza strip and listening to stories about the heroism of Palestinian women in order to contribute to the spirit of resistance in the novel being written. Like the other two narrators, she wants to write a story of her nation too. And to do that, she has to have a rich memory about life back home. Her father and her uncle have suffered exile and imprisonment from Palestine and in Palestine respectively. With a Jordanian passport, Miriam's situation as a Palestinian woman is even worse. The Egyptian border soldier refuses to grant her admission into Gaza (14). She objects to this: "You Egyptian office . why do you insist on practicing the role of the occupation soldier even after their disappearance? Why insist on reminding me of my exile and scattered parts here and there?" (17). On her first day in Gaza, Miriam experiences conflicting emotions ranging between happiness and sadness, which highlights her borderlands, ambivalent existence:

"Should I be happy that I breathe the air of my country and walk on its soil!! Or should I be sad for the long-term alienation and enforced exile of my father and his life lost between exile and homesickness!!" (58) Like her father who does not sleep his first night in exile, she exhibits the same feeling in her lost but not exactly found country. She says: "And I am like you my father; never closed an eye!! Never slept the first night in my country!!" (59) In Gaza, however, things are different because the colonizer stays out of the borders where Palestinian culture and traditions are dominant. In 1994, Israeli forces withdrew from Gaza strip, leaving much devastation and poverty behind. However, this did not break the will of resistance among Palestinians living there. Even women demonstrated exemplary lessons in the fight against occupation. Thus, Miriam gets to observe this and listen to first-hand stories about the role of women in resistance and nation building. Despite the lessons Miriam learns, dominant feelings are those of exile from Gaza (as she lives in Amman).

In a conversation between a Jewish prison officer and a Palestinian prisoner, Al-Sheikh Ali, the prisoner indicates that the colonizer treats Palestinians as a problem in their homeland. Al-Sheik Ali, an inmate with Abu-Raja, captures the essence of being a problem and "unhomed" when he asserts: "We have become a nation without land; the word Palestinian has become a bad omen no one dares to use!!" (114). For the Palestinian prisoner, being a Palestinian became a curse and an indication of inferiority. And this status is closely related to being treated by the colonizer as second-class citizens in their own land. Palestinians are seen as a problem in their country and as strangers in their homeland; they cannot live free from this veil of discrimination inside their country (under checkpoints and artificia borders) or outside when dealing with Arabs or the rest of the world.

\section{CONCLUSION}

People in Abu-Nab'ah's novel Oh, Allah, I Delivered a Female Child are treated as if their existence has been a problem since they were born. Palestinians around the world similarly live in the borderlands, behind the veil of misunderstanding, prejudice, and stereotyping. They are the unhappy hybrids of two cultures, the Palestinian culture and the imposed Israeli culture or the Palestinian culture and non-Palestinian one. They can neither separate themselves from their native identity nor fully assimilate with another. Hence, this article has attempted to examine the effects of living in the borderlands on Palestinians by applying relevant postcolonial theories-namely by Anzaldúa, Du Bois, and Bhaba-to Abu-Nab'ah's novel. According to AbuNab'ah, Palestinians suffer everywhere from being in-between (inhabiting in the borderlands space) and, thus, being rejected or discriminated against. Abbas suffers in Libya due to the veil of prejudice and stereotypes. Abu-Raja, who is in Palestine, lives in the borderlands behind prison bars and under humiliation. In Gaza, which is besieged by Israel, Palestinians-as Miriam observes-live in the borderlands too. They cannot live a normal life of dignity. They have to use underground tunnels and face Israeli attacks. In conclusion, colonization has led all Palestinians-wherever they are-to live in the borderlands status, fighting to unveil their cause and suffering from being treated as a problem in their homeland. In this sense, Abu-Nab'ah's novel is a counter-narrative to the colonizer's hegemonic stratagems and discourses. It is part of a cultural campaign against the 
dislocation experienced by those who live in the borderlands.

\section{ENDNOTE}

1 Authors' translation; all subsequent translations from the Arabic novel are ours.

\section{REFERENCES}

Abu-Nab'ah,Nerdeen. Oh, Allah, I Delivered a Female Child. Beirut, Lebanon: Arab Institution For Studies and Publishing, 2015. Print
Abu-Nab'ah, Nerdeen. Personal Interview. Interviewed by Asma’ Badran. May 2, 2017.

Anzaldúa, Gloria. Borderlands/La Frontera: The New Mestiza. San Francisco: Aunt Lute Books, 1987. Print.

Bhabha, Homi. The Location of Culture. London: Routledge, 1994. Print.

Du Bois, W. E. B. The Souls of Black Folk. Ebook.

Said, Edward W. Reflections on Exile and Other Essays. Cambridge, MA: Harvard UP, 2002. Print.

Tyson, Lois. Critical Theory Today: A User-Friendly Guide. $2^{\text {nd }}$ ed. New York: Routledge, 2006. Print. 